\title{
PELATIHAN TEKNIK JARIMATIKA BAGI SISWA MI WILAYAH FATIMATUZ ZAHRO PONDOK PESANTREN NURUL JADID
}

\author{
Arini Hidayati ${ }^{1}$, Siti Fatimah $^{2}$, Masrurotul Khasanah ${ }^{3}$, Sasmiati $^{4}$, Musyarrofah $^{5}$, \\ Qurrotud Diana ${ }^{6}$, Siti Naiesa ${ }^{7}$ \\ ${ }^{1,2,3,4,5,6,7)}$ Program Studi Pendidikan Matematika, Fakultas Sosial dan Humaniora, Universitas Nurul Jadid \\ e-mail: arinda3Lreza@gmail.com
}

\begin{abstract}
Abstrak
Kegiatan pengabdian masyarakat ini dilaksanakan oleh tim KKN Program Studi Pendidikan Matematika, Fakultas Sosial dan Humaniora, Universitas Nurul Jadid, yang bertempat di Wilayah Fatimatuz Zahro, Ponpes Nurul Jadid, Paiton Probolinggo. Peserta pelatihan merupakan siswa MI yang berstatus santri di Ponpes Nurul Jadid. Kegiatan pengabdian ini dimotivasi karena adanya kecenderungan guru yang memaksa siswa untuk menghafal dalam menyampaikan konsep operasi bilangan. Hal ini dapat menyebabkan siswa menjadi bosan dan menghasilkan nilai matematika yang rendah. Oleh karena itu, kami bermaksud untuk memberikan pelatihan teknik jarimatika kepada siswa MI di wilayah Ponpes Nurul Jadid, dengan tujuan supaya mereka lebih tertarik dalam belajar matematika dan lebih mudah dalam menyelesaikan operasi bilangan, khususnya operasi perkalian dan pembagian. Pelatihan Jarimatika memberikan teknik perhitungan matematika dengan cepat, tepat dan menyenangkan melalui perhitungan menggunakan jari tangan. Dengan teknik jarimatika dapat memberikan inovasi untuk belajar matematika tanpa menggunakan alat hitung. Kegiatan pelatihan dilaksanakan selama dua hari. Kegiatan ini dapat berjalan dengan dukungan semangat para peserta untuk memahami penerapan jarimatika. Hasil dari pelatihan ini diantaranya, peserta lebih termotivasi dan antusias dalam belajar matematika, dan meningkatnya kemampuan mereka dalam melakukan perhitungan dengan cepat dan tepat dengan menggunakan jari. Melalui pelatihan ini semoga dapat merubah paradigma bahwa matematika tidak sulit tetapi mudah dan meyenangkan.
\end{abstract}

Kata kunci: Jarimatika, Perkalian, Pembagian

\begin{abstract}
This community service activity is carried out by the KKN team of the Mathematics Education Study Program, Faculty of Social and Humanities, of University of Nurul Jadid, which is located in the Fatimatuz Zahro Area, of Nurul Jadid Islamic Boarding School, Paiton Probolinggo. The training participants were MI students with the status of santri at the Nurul Jadid Islamic Boarding School. This service activity is motivated by the tendency of the teacher to force students to memorize in conveying the concept of number operations. This can cause students to become bored and produce low math scores. Therefore, we intend to provide training in Jarimatika techniques to MI students in the Nurul Jadid Islamic Boarding School, with the aim of making them more interested in learning mathematics and making it easier to complete number operations, especially multiplication and division operations. Jarimatika training provides a fast, precise and fun method of calculating mathematics through calculations using your fingers. With the Jarimatika method, it can provide innovation for learning mathematics without using calculating tools. The training activities were carried out for two days. This activity can run with the enthusiasm of the participants to understand the application of Jarimatika. The results of this training included the participants being more motivated and enthusiastic about learning mathematics, and their increased ability to do calculations quickly and correctly using their fingers. Through this training, hopefully it can change the paradigm that mathematics is not difficult but easy and fun.
\end{abstract}

Keywords: Jarimatika, Multiplication, Division 


\section{PENDAHULUAN}

Pendidikan sangat penting untuk mengembangkan kualitas SDM dan membentuk manusia yang berkarakter (Nasution \& Surya, 2016). Manusia akan terbelakang dan sulit berkembang jika tanpa adanya pendidikan. Salah satu faktor untuk menciptakan pendidikan yang sukses adalah mata pelajaran pokok. Matematika adalah salah satu mata pelajaran pokok dan penting yang harus dikuasai sejak dini (Wardana, dkk., 2018).

Dalam kehidupan sehari-hari tidak lepas dari perhitungan matematika, misalnya transaksi jual beli, mengukur tinggi, menimbang berat badan, dan masih banyak yang lainnya. Oleh karena itu matematika adalah salah satu pelajaran yang paling penting dan sudah diperkenalkan kepada siswa sejak kelas 1 SD sampai SMA (Lanya H. dkk., 2020). Bahkan pelajaran matematika diajarkan dengan frekuensi yang lebih lama dibandingkan pelajaran yang lainnya (Hamdunah, dkk., 2014). Namun meski demikian pelajaran matematika dianggap pelajaran yang paling sulit, menakutkan dan tidak menyengkan oleh kebanyakan siswa (Sukriadi, dkk., 2019). Sehingga membuat pendidik menganggap pelajaran matematika sebagai "momok".

Kebanyakan siswa MI Wilayah Fatimatuz Zahro Ponpes Nurul Jadid, Paiton Probolinggo mengalami kesulitan ketika menyelesaikan permasalahan yang berkaitan dengan operasi hitung baik perkalian maupun pembagian. Hal ini ditunjukkan dengan rendahnya nilai matematika mereka di sekolah. Operasi perkalian sebenarnya merupakan operasi penjumlahan yang dilakukan secara berulang, dan operasi pembagian adalah operasi pengurangan yang berulang sampai habis (Nasution \& Surya, 2016). Dalam proses penyelesaian soal-soal matematika siswa yang berkemampuan berhitung yang tinggi dan cepat yang sangat cepat dalam menyelesaikan permasalahan matematika. Tapi sebaliknya, siswa yang kemampuan berhitungnya lambat cenderung lambat dalam penyelesaian permasalahan matematika. Oleh karena itu, yang menjadi perhatian utama di masing-masing tingkatan yaitu kemampuan berhitung siswa (Syaharuddin \& Mandailina, 2018). Dari hasil wawancara dengan siswa, alasan mereka kesulitan dalam melakukan operasi perhitungan matematika yaitu karena guru mereka cenderung memaksa untuk menghafal hasil perkalian dan pembagian bilangan, sehingga mereka merasa cepat bosan dan kurang bersemangat. Hal ini sesuai dengan pendapat (Husna, 2017) yang menyatakan bahwa rendahnya kemampuan berhitung siswa biasanya dipengaruhi oleh pembelajaran yang kurang begitu efektif dan juga pembelajaran yang dilaksanakan oleh guru yang hanya menggunakan metode ceramah sehingga membuat siswa tidak semangat. Selain itu, guru cenderung memaksa siswa untuk menghafal dalam mengajarkan konsep operasi hitung bilangan. Oleh karena itu dibutuhkan teknik untuk meningkatkan semangat dan kemampuan siswa untuk belajar lebih aktif lagi (Suryowati, dkk., 2016).

Saat ini banyak teknik dan metode yang digunakan untuk meningkatkan semangat siswa dalam belajar dan menguasai materi, dengan menggunakan teknik belajar yang tepat, maka pembelajaran matematika akan menjadi lebih mudah dan menyenangkan (Lanya H. dkk., 2020). Metode yang saat ini berkembang untuk pembelajaran matematika salah satunya adalah metode jarimatika, metode hitung dengan jari ini dirancang untuk mempermudah dalam melakukan operasi hitung, khususnya dalam menghitung operasi perkalian dan pembagian (Refianti, dkk., 2019). Jarimatika merupakan teknik perhitungan matematika dengan cepat, tepat dan menyenangkan melalui perhitungan menggunakan jari tangan (Hamdunah, dkk., 2014). Teknik jarimatika ini tidak hanya bisa digunakan oleh guru saja, tetapi orang tua juga bisa menggunakan teknik jarimatika ini di rumah. Karena peran guru, orang tua, dan tentunya niat guru teknik jarimatika ini diharapkan bisa membantu meningkatkan kemampuan matematika siswa khususnya dalam menghitung operasi perkalian dan pembagian (Payung, 2014).

\section{METODE}

\section{Jenis, Waktu, Tempat, Target/Sasaran}

Pelatihan metode jarimatika ini ditujukan bagi siswa MI Ponpes Nurul Jadid Paiton Probolinggo yang berada di Wilayah Fatimatuz Zahro. Alasan pemilihan siswa ini dikarenakan banyaknya siswa yang kesulitan dalam menyelesaikan soal yang berkaitan dengan operasi hitung perkalian dan pembagian. Adapun pelaksanaan pelatihan ini dilaksanakan selama dua hari, yaitu pada tanggal 27 dan 28 Februari 2021. Pelatihan teknik jarimatika ini adalah salah satu bentuk 
kegiatan pengabdian pada Masyarakat bagi Mahasiswa Program Studi Pendidikan Matematika semester V, Fakultas Sosial dan Humaniora, Universitas Nurul Jadid Paiton Probolinggo.

\section{Prosedur Pelaksanaan}

Adapun prosedur pelaksanaannya sebagai berikut:

1. Konfirmasi kepada pihak pengurus Pondok Pesantren Nurul Jadid khususnya Wilayah Fatimatuz Zahro karena kegiatan dilaksanakan di asrama berhubungan dengan adanya pandemi virus corona,

2. Menyepakati jadwal pelatihan dengan pihak wilayah

3. Menyiapkan lokasi, perlengkapan, dan segala kebutuhan selama pelatihan, dan

4. Melaksanakan pelatihan sesuai dengan jadwal yang telah susun dan disepakati.

\section{Tahap Pelaksanaan}

Tahap-tahap pelaksanaan kegiatan pelatihan ini antara lain:

1. Menyiapkan kelas dengan suasana yang rileks dan menyenangkan,

2. Menjelaskan tujuan pembelajaran yang akan dicapai dalam kegiatan pelatihan,

3. Peserta pelatihan diberikan soal pre-test yang berisi soal-soal perkalian dan pembagian, hal ini bertujuan untuk mengukur kemampuan operasi hitung peserta, khususnya perkalian dan pembagian,

4. Mengajarkan teknik jarimatika kepada para peserta pelatihan untuk operasi perkalian dan pembagian, sesuai dengan rancangan pembelajaran yang telah disusun,

5. Membimbing dan memberikan penguatan kepada peserta yang aktif, dan

6. Memberikan soal post-test untuk mengukur kemampuan akhir peserta setelah mengikuti rangkaian kegiatan pelatihan, hal ini juga untuk mengetahui apakah kemampuan hitung perkalian dan pembagian peserta meningkat atau tidak setelah mengikuti pelatihan.

\section{HASIL DAN PEMBAHASAN}

Kegiatan pelatihan jarimatika ini merupakan kegiatan pengabdian kepada masyarakat yang dilaksanakan oleh 1 orang dosen yang dibantu oleh 6 orang mahasiswa. Pelatihan dilaksanakan selama dua hari dengan durasi 120 menit untuk setiap pertemuan, dan dilaksanakan setelah jam pulang sekolah. Hari pertama pelatihan dikhususkan untuk operasi hitung perkalian, sedangkan hari kedua dikhususkan untuk operasi hitung pembagian. Kegiatan ini diikuti oleh 12 orang siswa dari berbagai tingkatan, mulai dari kelas 4,5 , dan 6. Semua peserta dapat mengikuti kegiatan pelatihan dari awal hingga akhir.

Pada hari pertama pelatihan, yakni tanggal 27 Februari 2021, hal pertama yang dilakukan yaitu pemateri menyiapkan kelas dengan suasana yang rileks dan menyenangkan supaya para peserta antusias dalam mengikuti kegiatan pelatihan. Selanjutnya pemateri menyampaikan tujuan pembelajaran yang akan dicapai selama kegiatan pelatihan. Sebelum teknik perhitungan jarimatika diajarkan, para peserta diberikan soal pre-test yang berisi soal-soal perkalian dan pembagian, untuk mengukur kemampuan operasi hitung peserta, khususnya perkalian dan pembagian. Waktu pengerjaan soal pre-test adalah selama 15 menit. Di bawah ini merupakan tabel hasil pre-test peserta.

Tabel 1 Hasil Pre-Test Peserta

\begin{tabular}{|c|c|c|c|}
\hline No. & Inisial Nama Peserta & Nilai & Keterangan \\
\hline 1 & AB & 76 & Tuntas \\
\hline 2 & FAT & 64 & Belum tuntas \\
\hline 3 & GBR & 60 & Belum tuntas \\
\hline 4 & GFK & 56 & Belum tuntas \\
\hline 5 & IS & 80 & Tuntas \\
\hline 6 & IR & 82 & Tuntas \\
\hline 7 & NDA & 78 & Tuntas \\
\hline 8 & NZM & 68 & Belum tuntas \\
\hline 9 & RAW & 70 & Belum tuntas \\
\hline 10 & SFW & 76 & Tuntas \\
\hline 11 & SAQ & 78 & Tuntas \\
\hline 12 & WA & 68 & Belum tuntas \\
\hline
\end{tabular}


Dari tabel di atas dipat dilihat bahwa sebanyak $50 \%$ peserta dinyatakan tuntas mengerjakan soal pre-test dengan KKM 75. Sedangkan 50\% lainnya masih dinyatakan belum tuntas. Rata-rata nilai pre-test mereka adalah 71,33. Hasil tersebut menunjukkan bahwa kemampuan dan kecepatan berhitung peserta masih lumayan rendah dengan batas waktu yang diberikan. Sehingga dapat disimpulkan bahwa mereka membutuhkan pelatihan teknik berhitung yang bisa membantu mereka dalam melakukan perhitungan secara cepat dan tepat, terutama untuk operasi hitung perkalian dan pembagian.

Selanjutnya peserta dibagi menjadi 6 kelompok, dengan setiap kelompok beranggotakan dua orang, dan masing-masing kelompok didampingi oleh satu orang mahasiswa. Sedangkan dosen bertindak sebagai pemateri yang menjelaskan teknik perhitungan jarimatika, dengan dibantu 6 orang mahasiswa yang bertugas mendampingi masing-masing kelompok. Awal mulanya para peserta merasa cukup kebingungan dengan teknik jarimatika yang dijelaskan, karena teknik perhitungan ini masih baru untuk mereka. Namun seiring berjalannya waktu mereka dapat menerima materi dengan baik dan sangat antusias memperhatikan penjelasan pemateri. Pada hari pertama ini, pelatihan dikhususkan untuk operasi hitung perkalian. Gambar di bawah ini merupakan contoh teknik jarimatika untuk operasi perkalian.
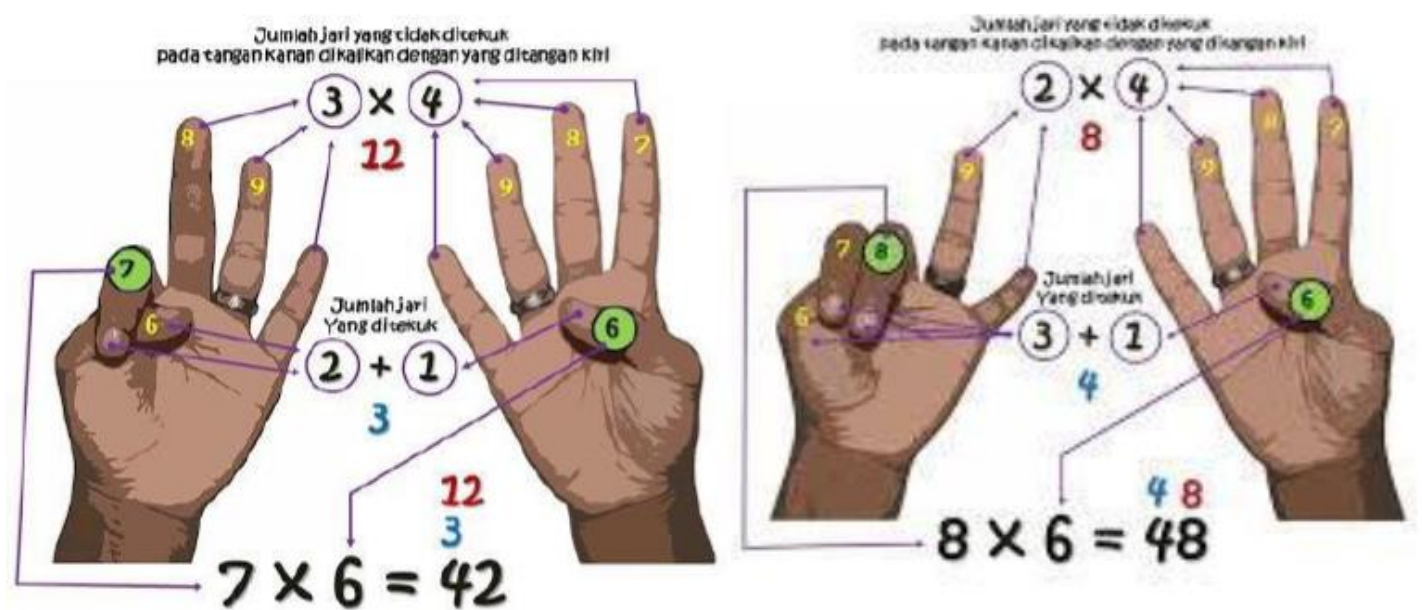

Gambar 1 Teknik Jarimatika untuk Operasi Perkalian

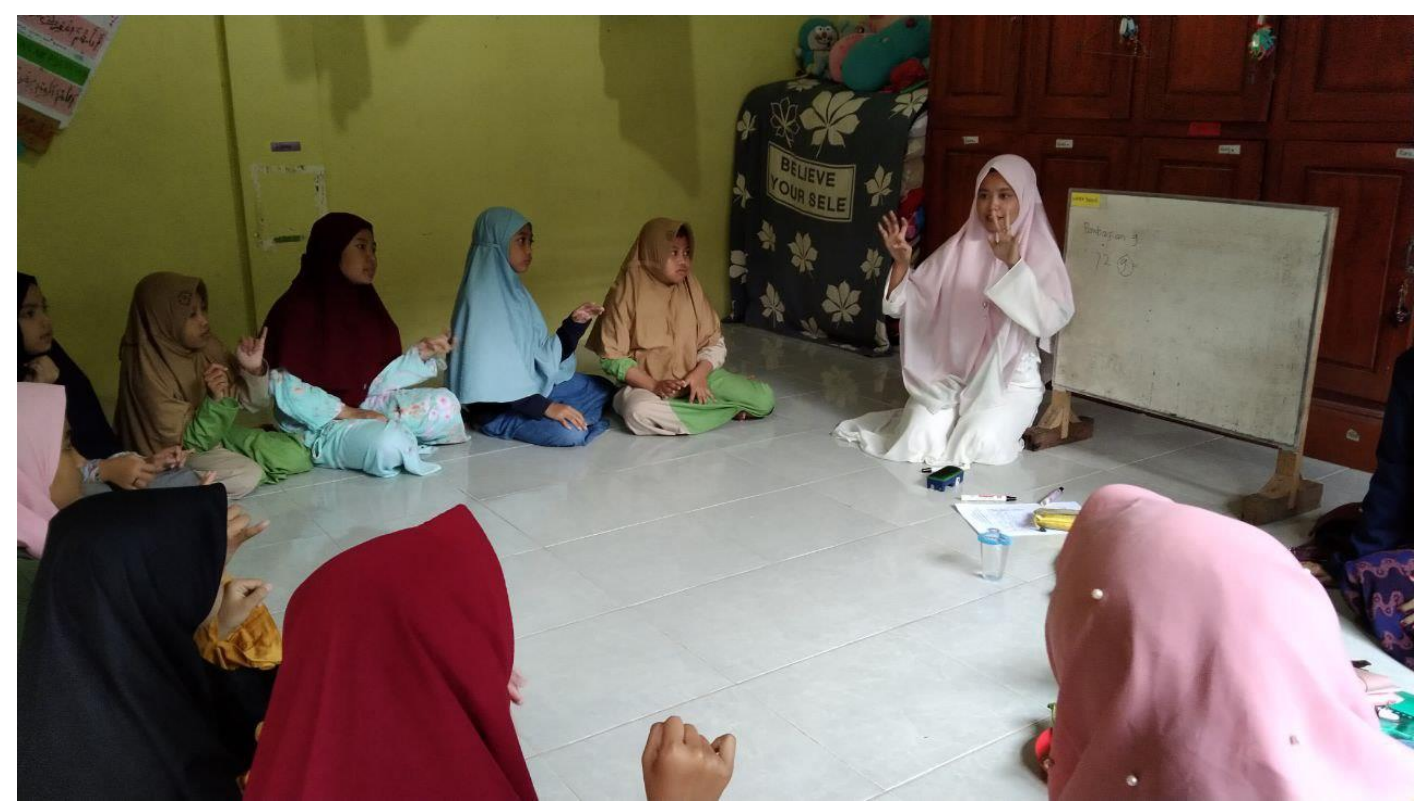

Gambar 2 Penjelasan Teknik Jarimatika oleh Pemateri 


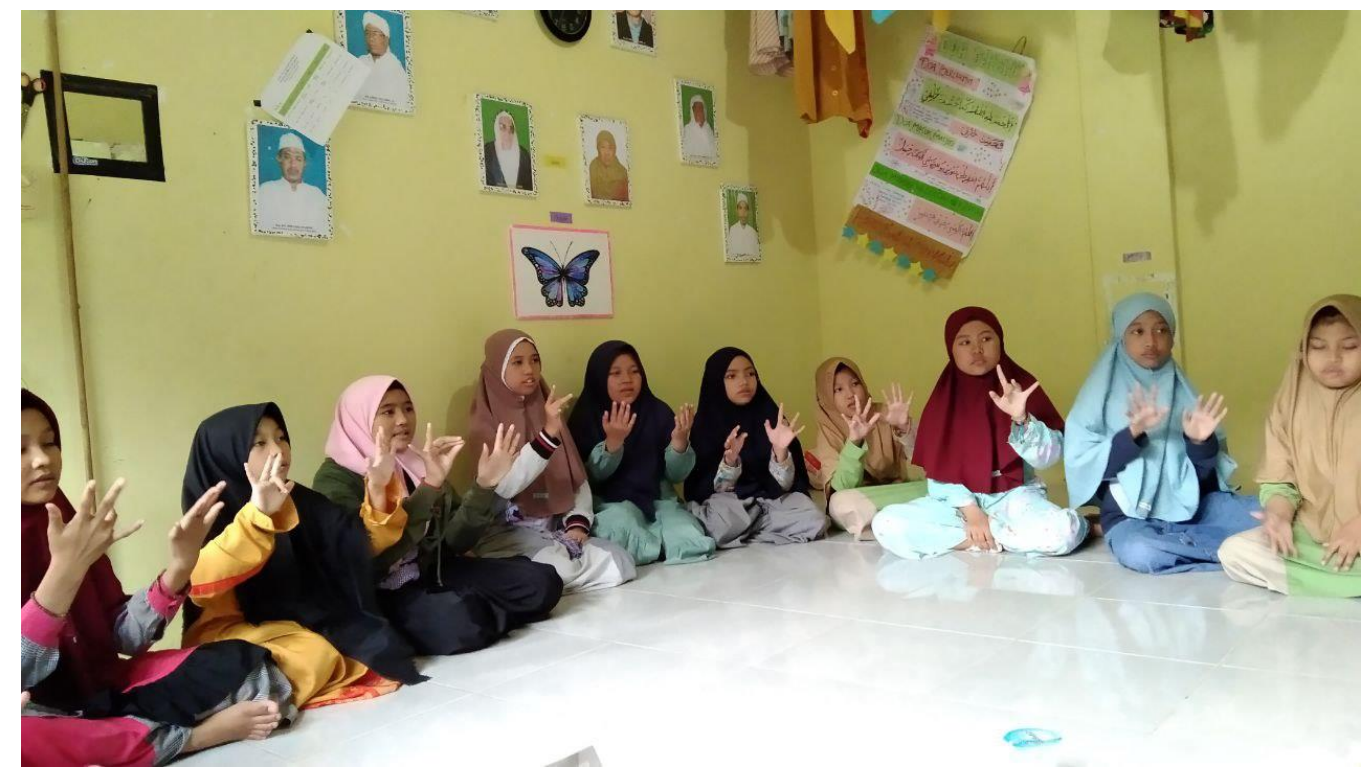

Gambar 3 Praktik Teknik Jarimatika oleh Para Peserta

Pelatihan pada hari kedua yang dilaksanakan pada tanggal 28 Fabruari 2021 dikhususkan untuk operasi hitung pembagian. Pada hari kedua ini kegiatan yang dilakukan tidak jauh berbeda dengan kegiatan yang dilakukan pada hari pertama. Peserta diberikan pelatihan dan penjelasan tentang teknik jarimatika untuk operasi hitung pembagian. Sama dengan hari pertama, pada hari kedua ini para peserta juga sangat antusias dan bersemangat dalam mengikuti semua rangkaian kegiatan. Peserta aktif bertanya jika ada hal-hal yang tidak dipahami. Mereka juga saling membantu satu sama lain, sehingga suasan kegiatan pelatihan hidup dan menyenangkan. Pada bagian akhir diberikan soal post-test untuk mengukur kemampuan akhir para peserta setelah mengikuti kegiatan pelatihan. Durasi pengerjaan soal post-test adalah 15 menit, dengan KKM 75. Berikut hasil post-test para peserta.

Tabel 2 Hasil Pot-Test Peserta

\begin{tabular}{|c|c|c|c|}
\hline No. & Inisial Nama Peserta & Nilai & Keterangan \\
\hline 1 & AB & 88 & Tuntas \\
\hline 2 & FAT & 82 & Tuntas \\
\hline 3 & GBR & 80 & Tuntas \\
\hline 4 & GFK & 80 & Tuntas \\
\hline 5 & IS & 100 & Tuntas \\
\hline 6 & IR & 98 & Tuntas \\
\hline 7 & NDA & 90 & Tuntas \\
\hline 8 & NZM & 84 & Tuntas \\
\hline 9 & RAW & 86 & Tuntas \\
\hline 10 & SFW & 88 & Tuntas \\
\hline 11 & SAQ & 100 & Tuntas \\
\hline 12 & WA & 90 & Tuntas \\
\hline
\end{tabular}

Berdasarkan tabel di atas dapat diketahui bahwa $100 \%$ peserta dinyatakan tuntas dalam menyelesaikan soal post-test, dengan rata-rata nilai 88,83 . Dari hasil tersebut dapat dilihat bahwa semua peserta dapat menyelesaikan soal post-test dengan baik. Bahkan sebagian dari mereka ada yang menyelesaikan soal post-test sebelum waktu yang ditentukan berakhir. Sehingga dapat disimpulkan bahwa kemampuan dan kecepatan berhitung peserta meningkat setelah mengikuti kegiatan pelatihan. Hal ini sesuai dengan pendapat Husna (2017) bahwa peningkatan kemampuan perhitungan siswa setelah mengikuti pelatihan metode jarimatika meningkat cukup baik. Hal serupa juga dinyatakan oleh Syaharuddin dan Mandailina (2018) yang mengatakan bahwa pelatihan jarimatika sangat bermanfaat dan sangat membantu meningkatkan kemampuan berhitung 
siswa. Penelitian yang dilakukan oleh Sukriadi, dkk. (2019) menunjukkan bahwa metode jarimatika dapat meningkatkan hasil belajar siswa sekolah dasar. Hasil penelitian yang dilakukan oleh Suryowati, dkk. (2016) juga menunjukkan bahwa teknik jarimatika dapat membantu siswa menyelesaikan latihan perhitungan dengan cepat dan benar. Pramita (2017) juga menyatakan bahwa dengan mempelajari jarimatika dapat membantu siswa melakukan perhitungan dengan lebih cepat dan cermat, serta mampu meningkatkan semangat belajar siswa.

Secara umum kegiatan pelatihan teknik jarimatika baik pada hari pertama maupun hari kedua berjalan dengan lancar berkat kerjasama yang baik antara dosen, mahasiswa, dan para peserta. Semua materi pelatihan dapat tersampaikan dengan baik oleh tim pemateri. Para peserta yang aktif diberikan penguatan dan reward. Sedangkan untuk para peserta yang kurang aktif diberikan pendampingan secara khusus supaya nantinya mereka juga bisa memahami dan menerapkan teknik jarimatika ini dengan baik dan maksimal. Para peserta juga sangat antusias dan bersemangat dalam mengikuti semua rangkaian kegiatan pelatihan. Semua peserta memberika respon postif terhadap kegiatan ini dan mereka merasa sangat senang. Bahkan sebagian besar dari mereka merasa kurang mengikuti pelatihan ini, mereka meminta supaya pelatihan jarimatika ini ditambah waktu pelaksanaannya. Karena dengan adanya pelatihan ini mereka merasa sangat terbantu terutama dalam menyelesaikan tugas matematika dari sekolah. Sesuai dengan pendapat Nasution dan Surya (2016) yang menyatakan bahwa penggunaan jarimatika membuat para siswa menjadi lebih senang dalam mengikuti kegiatan pembelajaran sehingga tujuan pembelajaran dapat dicapai secara maksimal. Demikian pula dengan pendapat Suryowati, dkk. (2016) yang menyatakan bahwa dengan teknik jarimatika mampu mengubah paradigma bahwa pelajaran matematika menjadi mudah, asyik, dan menyenangkan.

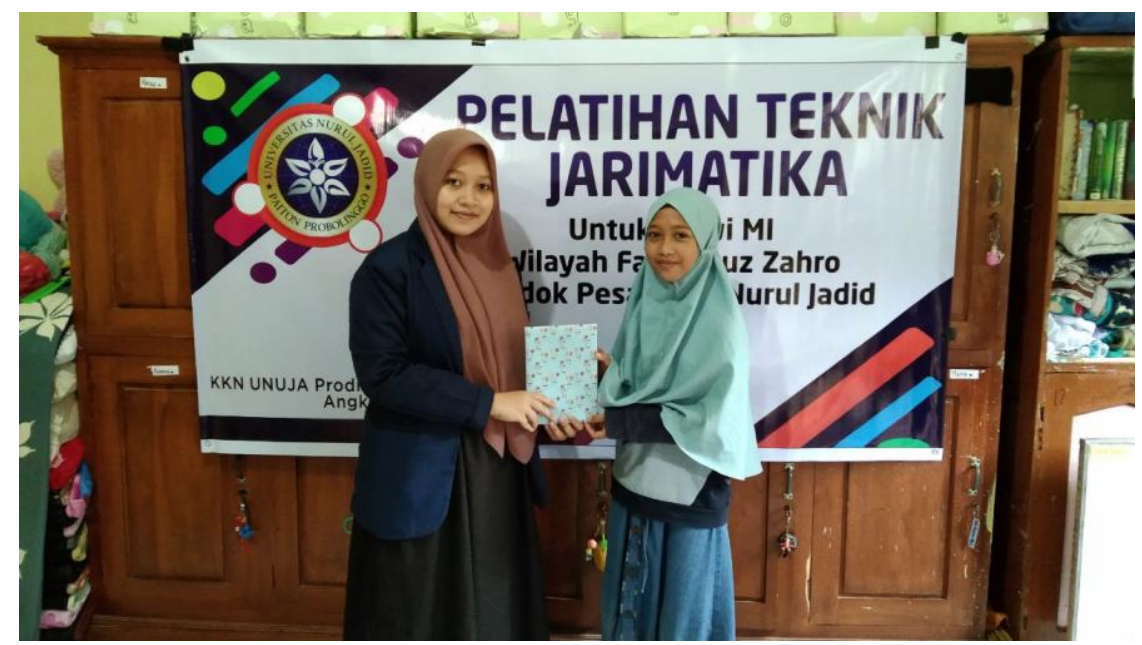

Gambar 4 Pemberian Hadiah Kepada Peserta Aktif dan Berprestasi

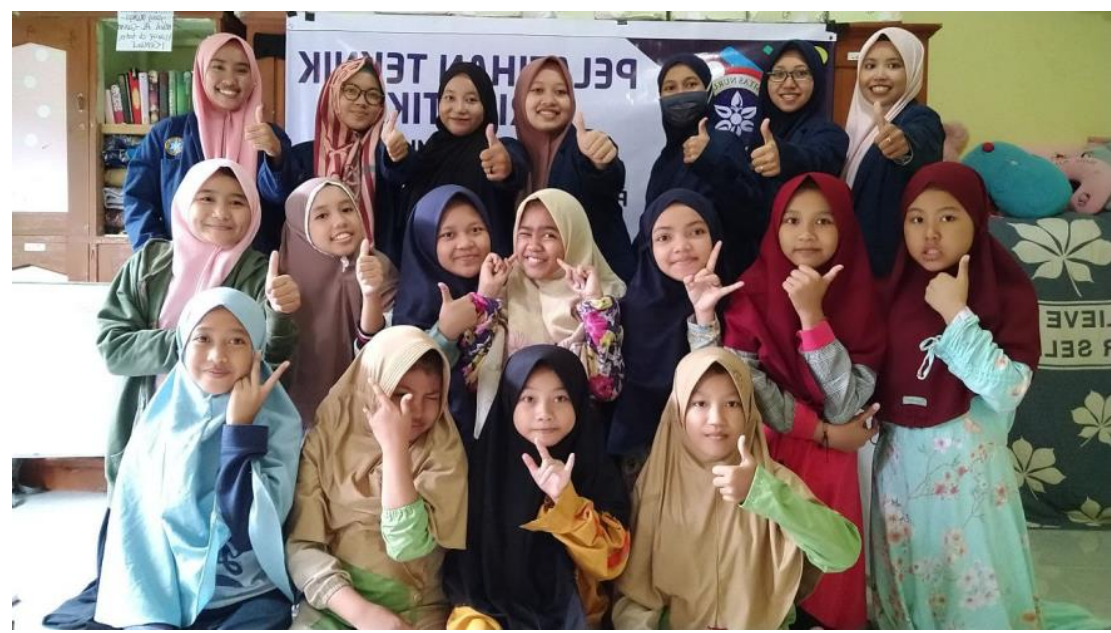

Gambar 5 Para Pemateri dan Peserta 


\section{SIMPULAN}

Kegiatan pelatihan teknik jarimatika ini merupakan kegiatan pengabdian masyarakat yang dilaksanakan oleh tim KKN Program Studi Pendidikan Matematika, Fakultas Sosial dan Humaniora, Universitas Nurul Jadid. Kegiatan ini ditujukan bagi siswa MI Ponpes Nurul Jadid Paiton Probolinggo yang berada di Wilayah Fatimatuz Zahro. Hasil dari kegiatan ini menunjukkan bahwa adanya peningkatan kemampuan dan kecepatan berhitung para peserta terutama untuk operasi perkalian dan pembagian. Sebelum dilakukan pelatihan, hasil pre-test menunjukkan bahwa hanya $50 \%$ peserta yang dinyatakan tuntas sedangkan $50 \%$ lainnya belum tuntas, dengan rata-rata nilai pre-test yaitu 71,33 dengan KKM yang ditentukan yaitu 75 . Setelah mengikuti kegiatan pelatihan jarimatika, hasil post-test menunjukkan bahwa sebanyak $100 \%$ peserta dinyatakan tuntas dengan rata-rata nilai post-test yaitu 88,83. Para peserta juga sangat antusias dan bersemangat mengikuti kegiatan pelatihan. Mereka semua mengaku sangat senang dan memberikan respon positif terhadap kegiatan pelatihan ini. Dengan demikian, dapat disimpulkan bahwa teknik jarimatika dapat meningkatkan kemampuan dan kecepatan berhitung peserta, terutama untuk operasi perkalian dan pembagian. Teknik jarimatika juga dapat mengubah paradigma bahwa belajar matematika tidak lagi sulit, tetapi mudah dan menyenangkan.

\section{SARAN}

Saran yang dapat kami sampaikan yaitu perlunya diadakan pelatihan lanjutan dikarenakan keterbatasan waktu dan siswa. Pelatihan selanjutnya bisa dilaksanakan di wilayah lain di Ponpes Nurul Jadid, mengingat banyaknya siswa MI di wilayah-wilayah tersebut. Untuk siswa MI kelas 1 s/d kelas 2 mungkin bisa diberikan pelatihan teknik jarimatika untuk operasi hitung penjumlahan dan pengurangan terlebih dahulu.

\section{UCAPAN TERIMA KASIH}

Penulis mengucapkan terima kasih kepada seluruh pihak yang telah mendukung terlaksananya kegiatan pelatihan ini, khususnya pihak pengasuh dan pengurus Wilayah Fatimatuz Zahro Ponpes Nurul Jadid yang telah memberikan izin kepada kami untuk melaksanakan kegiatan pelatihan di wilayah tersebut, dan LP3M Universitas Nurul Jadid yang telah memberikan dukungan financial terhadap kegiatan pengabdian masyarakat ini.

\section{DAFTAR PUSTAKA}

Hamdunah, Fitri, D. Y., \& Cesaria, A. (2014). Pelatihan Jarimatika Perkalian bagi Guru-Guru di SDN 02 Lubuk Buaya. Jurnal LEMMA, 1(1), 20-25.

Husna, A. (2017). Pelatihan Penggunaan Metode Jarimatika untuk Menanamkan Konsep Cara Mudah Menghitung Perkalian pada Siswa Sekolah Dasar RW. 01 Kelurahan Kibing. Jurnal Minda Baharu, 1(1), 19-24.

Lanya, H., Aini, S. D., \& Irawati, S. (2020). Pelatihan Metode Jarimatika sebagai Alternatif dalam Pembelajaran Matematika SD. Jurnal Pengabdian pada Masyarakat, 5(2), 390-398.

Nasution, T. K., \& Surya, E. (2016). Penerapan Teknik Jarimatika dalam Upaya Meningkatkan Kemampuan Operasi Hitung Perkalian Bilangan. UNION: Jurnal Pendidikan Matematika, 4(2), 239-272.

Payung, Z. (2014). Penerapan Jarimatika untuk Meningkatkan Kecepatan Berhitung Perkalian Bilangan Asli Siswa Kelas IV SDN 184 Inpres Ulusalu. Jurnal KIP, 3(2), 563-573.

Pramita, D. (2017). Pengenalan dan Pelatihan Berhitung dengan Jarimatika dan Sempoa di SDN 10 Ampenan. Jurnal Masyarakat Mandiri, 1(1), 46-51.

Refianti, M., Hartini, S., \& Gunandi, F. (2019). Kemampuan Operasi Perkalian Siswa Tunanetra Menggunakan Metode Jarimatika. Prosiding Seminar Matematika dan Sains Departemen Pendidikan Matematika dan Pendidikan Biologi FKIP Universitas Wiralodra, (pp. 60-67). Indramayu, 19 September.

Sukriadi, Rahmah, H., \& Sere, N. (2019). Peningkatan Hasil Belajar Matematika Materi Perkalian melalui Metode Jarimatika pada Siswa Kelas II Sekolah Dasar. Proceeding Seminar Nasional Ilmu Pendidikan FKIP UNMUL I, (pp. 78-86). Samarinda, 24 Agustus. 
Suryowati, K., Setyawan, Y., \& Jatipaningrum, M. T. (2016). Pelatihan Jarimatika untuk Inovasi Pembelajaran Matematika bagi Jamaah Musholla Al-Hidayah Desa Sukoharjo, Kec. Ngaglik, Sleman, Yogyakarta. Jurnal Statistika Industri dan Komputasi, 1(1), 80-86.

Syaharuddin, \& Mandailina, V. (2018). Meningkatkan Kemampuan Berhitung Siswa SD Menggunakan Metode Jarimatika. JCES FKIP UMMat, 1(1), 30-33.

Wardana, P. D., Suyitno, \& Handayani, D. E. (2018). Keefektifan Jarimatika bagi Hasil Belajar Materi Perkalian Bilangan pada Siswa Kelas II SD Genting 02 Kecamatan Jambu Kabupaten Semarang. Prosiding Seminar Nasional Himpunan Mahasiswa Program Studi PGSD Bekerjasama dengan Program Studi PGSD, (pp. 590-598). Semarang, 9 Mei. 